\title{
Immobilisation of Cell-Binding Peptides on Poly-e- Caprolactone (PCL) Films: A Comparative XPS Study of Two Chemical Surface Functionalisation Methods
}

DOI:

10.1002/jbm.a.34345

\author{
Document Version \\ Accepted author manuscript
}

Link to publication record in Manchester Research Explorer

Citation for published version (APA):

Stevens, J. S., S Stevens, J., C de Luca, A., Pelendritis, M., Terenghi, G., Downes, S., \& L M Schroeder, S. (2014). Immobilisation of Cell-Binding Peptides on Poly-e-Caprolactone (PCL) Films: A Comparative XPS Study of Two Chemical Surface Functionalisation Methods. Surface and Interface Analysis, 46(10-11), 673-678. https://doi.org/10.1002/jbm.a.34345

Published in:

Surface and Interface Analysis

\section{Citing this paper}

Please note that where the full-text provided on Manchester Research Explorer is the Author Accepted Manuscript or Proof version this may differ from the final Published version. If citing, it is advised that you check and use the publisher's definitive version.

\section{General rights}

Copyright and moral rights for the publications made accessible in the Research Explorer are retained by the authors and/or other copyright owners and it is a condition of accessing publications that users recognise and abide by the legal requirements associated with these rights.

\section{Takedown policy}

If you believe that this document breaches copyright please refer to the University of Manchester's Takedown Procedures [http://man.ac.uk/04Y6Bo] or contact uml.scholarlycommunications@manchester.ac.uk providing relevant details, so we can investigate your claim.

\section{OPEN ACCESS}




\title{
Immobilisation of Cell-Binding Peptides on Poly- $\varepsilon$-Caprolactone (PCL) Films: A Comparative XPS Study of Two Chemical Surface
}

\section{Functionalisation Methods}

Joanna S. Stevens ${ }^{1}$, Alba C. de Luca ${ }^{2,3}$, Sandra Downes ${ }^{3}$, Giorgio Terenghi ${ }^{2}$, Sven L. M. Schroeder ${ }^{1,4} *$

${ }^{1}$ School of Chemical Engineering and Analytical Science, The University of Manchester, Oxford Road, Manchester, M13 9PL, UK

${ }^{2}$ Blond McIndoe Laboratories, Regenerative Medicine, Institute of Inflammation and Repair, The University of Manchester, Manchester Academic Health Science Centre, Oxford Road, Manchester M13 9PT, UK

${ }^{3}$ School of Materials, The University of Manchester, Grosvenor Street, Manchester M13 9PL, UK

${ }^{4}$ School of Chemistry, The University of Manchester, Brunswick Street, Manchester, M13 9PL, UK

Email: s.schroeder@manchester.ac.uk

*Sven L.M. Schroeder: Tel. +44-161-306 4502; Fax: +44-161-306 8867

\begin{abstract}
Successful interaction between cells and biomaterial surfaces is crucial for biomedical devices, and incorporation of peptides such as RGD (Arg-Gly-Asp) at the polymer interface can substantially promote cell adhesion and proliferation. X-ray photoelectron spectroscopy (XPS) has been used to characterise poly- $\varepsilon$-caprolactone (PCL) films modified by aminolysis and the introduction of RGD peptides via carbodiimide (CDI) and thiol-halogen álickô chemistry. The nitrogen signal acts as an elemental indicator for successful attachment, and changes in the chemical environment are reflected in the carbon and oxygen spectra. Chlorine and sulphur provide additional chemical indicators of reaction progress in the thiol method, with the selective nature of the $\mathrm{Cl}-\mathrm{S}$ reaction reflected in the complete loss of $\mathrm{Cl}$ signal and appearance of $S$, avoiding potential amine-peptide side-reactions. Comparison of the XPS elemental concentrations indicated an estimate of 2-3\% peptide functionalisation on the PCL surface for both methods, correlating with the improvement in Schwann cell response observed after peptide immobilisation. The enhanced selectivity of peptide attachment to the polymer surface demonstrated with XPS for the novel method based on thiol chemistry shows its potential for development as a biomimetic scaffold for peripheral nerve injury.
\end{abstract}




\section{Keywords}

Polymer, surface modification, substrate, RGD, biomaterial, scaffolds, cell response, X-ray photoelectron spectroscopy

\section{Introduction}

Limited availability of autografts means biomaterial substitutes are often needed to act as scaffolds, such as for peripheral nerve injury (Figure 1), one of the most common traumas. ${ }^{[1]}$ Cell-material interactions are crucial for cell adhesion and proliferation on biomaterial surfaces, with immobilisation of biomolecules leading to the formation of biomimetic substrates, improving cell response. RGD (Arg-Gly-Asp, Figure 2) is one of the most studied peptides for biopolymer functionalisation ${ }^{[2-6]}$ and can trigger different cell lines to adhere and proliferate on the surface. ${ }^{[7]}$ Characterising the chemical modification of polymer film surfaces and therefore the extent of peptide attachment on the surface is critical, although the surface nature of the functionalisation means monitoring the success of peptide immobilisation through standard material characterisation techniques is not always feasible.

$\mathrm{X}$-ray photoelectron spectroscopy (XPS) is a surface-sensitive technique, with probing depths of typically $<5 \mathrm{~nm}$ for organic materials, ${ }^{[8]}$ that provides element-specific chemical state information. XPS chemical shifts vary as a function of the chemical state of an element and its local chemical environment, ${ }^{[9]}$ and detailed characterisation of amino acids ${ }^{[10,11]}$ and peptides, including RGD ${ }^{[10]}$ has been carried out with XPS. In addition, XPS reveals the relative elemental composition at the surface through the peak areas, providing an estimate of the amount of peptide surface attachment. This makes the technique an ideal choice for characterising the chemical modification of biodegradable poly- $\mathrm{U}^{\circ}$ caprolactone (PCL) films for use as peripheral nerve conduits, identifying whether RGD-peptides have been successfully immobilised on the surface.

XPS was performed on PCL films functionalised with RGD peptides through the widely used carbodiimide (CDI) chemistry (Figure 2), ${ }^{[3,4,12]}$ and an innovative method ${ }^{[13]}$ based on thiol-halogen álickôchemistry, ${ }^{[14]}$ designed to avoid potential amine-peptide side-reactions and increase selectivity. Analysis of the PCL films at each stage of the reaction aims is performed with the aim of providing details of chemical changes occurring at the surface and the extent of peptide immobilisation on the substrate. 


\section{Experimental}

\section{PCL films}

All chemicals and reagents were purchased from Sigma- Aldrich Ltd. (Dorset, UK) unless otherwise stated. Schwann cells (SCs) were harvested and cultured as explained previously. ${ }^{[13]}$ PCL polymer pellets (Mn 70,000-90,000) were dissolved in dichloromethane (DCM) (Fisher Scientific, Leicestershire, UK) to yield the PCL solution $(3 \% \mathrm{wt} / \mathrm{v})$. PCL films were formed by casting the solution on glass coverslips $\left(18 \times 18 \mathrm{~mm}^{2}\right)$ and leaving the solution to evaporate overnight at room temperature. RGD peptide sequences were then immobilised on the PCL films using the carbodiimide (CDI) chemistry and thiol-halogen álickô chemistry methods and the morphology and focal adhesion of Schwann cells was monitored with fluorescence microscopy. ${ }^{[13]}$

\section{CDI chemistry (HMD/RGD):}

Step I - Aminolysis: PCL films were immersed in a $10 \% \mathrm{wt} / \mathrm{v}$ hexamethylenediamine (HMD)/2-propanol solution ( $\mathrm{pH} 7$ ) for $3 \mathrm{~h}$ at $40^{\circ} \mathrm{C}$, stirring continuously. Aminolyzed films were then washed carefully in distilled water and left to dry overnight.

Step II - Peptide immobilisation: 1-ethyl-3-(dimethylaminopropyl)carbodiimide (EDC) was dissolved in 2-N-morpholino-ethanesulfonic acid (MES) buffer $0.1 \mathrm{M}(\mathrm{pH} \sim 5.5)$ to increase its reactivity. An EDC solution 0.1M was then applied on the aminolyzed PCL film and left to react for $3 \mathrm{~h}$ at room temperature. The previous solution was then removed and a new solution was prepared with tri-peptide RGD and N-hydroxysuccinimide (NHS) in MES buffer $0.1 \mathrm{M}(\mathrm{pH} \sim 5.5)$. The final peptide concentration to spread on film surface was 0.2 $\mathrm{lg} / \mathrm{mm} 2 .^{[13]}$ The peptide solution was left to react for $24 \mathrm{~h}$ at room temperature. Samples were finally washed in distilled water and dried.

\section{Thiol chemistry (CEA/RGDSC):}

Step I - Aminolysis: PCL films were immersed in a $10 \% \mathrm{wt} / \mathrm{v}$ 2-chloroethylamine hydrochloride (CEA)/water solution $\left(\mathrm{pH}\right.$ 9) for $3 \mathrm{~h}$ at $40^{\circ} \mathrm{C}$, stirring continuously. Chlorinated films were then washed carefully in distilled water and left to dry overnight.

Step II - Peptide immobilisation: The pentapeptide RGDSC (Biomatik Corporation, Cambridge, Canada) and tris(2 carboxyethyl)phosphine hydrochloride (TCEP) were dissolved in MES buffer $0.1 \mathrm{M}(\mathrm{pH} \sim 5.5)$ in a molar ratio of 1:5, to obtain again a final peptide concentration of $0.2 \mathrm{lg} / \mathrm{mm} 2$ on the film surface. ${ }^{[13]}$ The solution was then applied on 
chlorinated films and left to react for $24 \mathrm{~h}$ at room temperature. Samples were finally washed in distilled water and dried.

\section{X-ray Photoelectron Spectroscopy (XPS)}

XP spectra were recorded with a Kratos Axis Ultra instrument employing a monochromatic $\mathrm{Al} \mathrm{K} \mathrm{K}_{\mathrm{U}}$ source $(1486.69 \mathrm{eV}) .{ }^{[15,16]}$ Surveys were measured with $80 \mathrm{eV}$ pass energy in steps of $0.25 \mathrm{eV}$, with $300 \mathrm{~ms}$ dwell time per data point. High resolution spectra were measured within the spectral range of interest (ca. $\pm 20 \mathrm{eV}$ around core level emission peaks) with a 20 $\mathrm{eV}$ pass energy, $0.1 \mathrm{eV}$ steps, and $300 \mathrm{~ms}$ dwell time per data point. For the functionalised films, the dwell time was increased up to $500 \mathrm{~ms}$ for C $1 \mathrm{~s}$ and $\mathrm{O} 1 \mathrm{~s}$ and $2000 \mathrm{~ms}$ for $\mathrm{N} 1 \mathrm{~s}, \mathrm{Cl}$ $2 \mathrm{p}$, and $\mathrm{S} 2 \mathrm{p}$ spectra to increase the sensitivity of detection.

Analysis of the data was carried out with Casa XPS software using a linear background and GL(30) line shape. ${ }^{[17]}$ The elemental compositions (relative atomic \%) were calculated using an $\mathrm{O} 1 \mathrm{~s}$ relative sensitivity factor (RSF) of 2.52 relative to $\mathrm{C} 1 \mathrm{~s} .{ }^{[15]}$ Samples were referenced to adventitious hydrocarbon contamination at $285 \mathrm{eV} \cdot{ }^{[15,16]}$ Repeatability of the peak positions was $\pm 0.1 \mathrm{eV}$. In the remaining text, when reporting binding energies for atoms in functional groups the atom referred to is underlined.

\section{Immunocytochemistry and fluorescence microscopy}

The morphology and the ability of Schwann cells to form focal adhesion on treated and untreated PCL films were investigated through immunocytochemistry. 5,000 cells were seeded on each film and cultured for 5 days. Afterwards, the medium was aspirated and the cells were carefully fixed in 4\% PFA for $20 \mathrm{~min}$ at room temperature. Cells were washed in phosphate buffered saline (PBS), permeabilized in $0.2 \%$ Triton-X/PBS and washed again in PBS. Non-specific antigens were blocked with $1 \%(\mathrm{w} / \mathrm{v})$ bovine serum albumin (BSA) for 1 $\mathrm{h}$ at room temperature. The primary antibody (Mouse Anti-S100 Antibody; 1:500 or AntiVinculin antibody (hVIN-1, Abcam, UK); 1:400) was applied overnight at $4^{\circ} \mathrm{C}$. Samples were washed in PBS before the secondary antibody (Alexa Fluor 568 donkey anti-mouse IgG, Life Technologies, UK; 1:1000) was applied for $1 \mathrm{~h}$ at room temperature in the dark. Samples were washed again in PBS and incubated with phalloidin (Alexa Fluor 488, Life Technologies, UK; 1:40) for $20 \mathrm{~min}$ at room temperature in the dark. Films were finally washed again in PBS and mounted on glass slides with Vectashield containing DAPI. Images were acquired at different magnification using a fluorescence microscope (Olympus BX60). 
Quantification of the length of cellular processes using S100 staining and the cell spreading expressed as cell area using Vinculin staining was performed with ImageJ software.

\section{Results and Discussion}

Comparison of the functionalised films requires characterisation of the substrate. Analysis of the untreated PCL film (Figure 3, top row) shows an elemental composition close to that expected from its known bulk composition $\left(\mathrm{C}_{6} \mathrm{H}_{10} \mathrm{O}_{2}\right.$, Table 1). A carbon content slightly higher than expected arises from adventitious hydrocarbon contamination that is ubiquitous in any laboratory environment and a known feature of surface analysis of organic materials. ${ }^{[15]} \mathrm{PCL}$ is solely comprised of carbon and oxygen, and the carbon $1 \mathrm{~s}$ (C 1s) emission spectrum of PCL was fitted with four peaks corresponding to increasingly electronegative chemical environments. ${ }^{[18]}$ These are (i) aliphatic $\underline{\mathrm{C}}-\mathrm{C}$ at $285 \mathrm{eV}$, (ii) carbon neighbouring ester groups $\underline{\mathrm{C}}-\mathrm{COO}$ at $285.3 \mathrm{eV}$, (iii) $\underline{\mathrm{C}}-\mathrm{O}$ species at $286.5 \mathrm{eV}$, and (iv) ester groups $\mathrm{O}=\underline{\mathrm{C}}-\mathrm{O}$ at $289.0 \mathrm{eV}$ (Figure 3, Table 2; note that the underlined element is the moiety responsible for the observed emission feature). Two photoemission peaks are observed in the $\mathrm{O} 1 \mathrm{~s}$ spectrum, reflecting the different electron density in the two ester oxygen environments, $\underline{\mathrm{O}}=\mathrm{C}-\mathrm{O}$ at $532.1 \mathrm{eV}$ and $\mathrm{O}=\mathrm{C}-\underline{\mathrm{O}}$ at $533.5 \mathrm{e} \mathrm{V}$ (Figure 3, Table 2).

Aminolysis of PCL with either hexamethylenediamine (HMD) or 2-chloroethylamine (CEA) through nucleophilic substitution at the ester bonds leads to formation of an amide bond (PCL-HMD or PCL-CEA, Figure 2 step I). The resulting chemical modification of the surface is observed by XPS through alteration in the elemental composition (Table 1), which becomes evident through the additional carbon and nitrogen photoemission features (Table 2). The nitrogen $1 \mathrm{~s}$ photoemission signal around $400 \mathrm{eV}$ is characteristic of an amide bond (Table 2). ${ }^{[18]}$ Broadening to low binding energy $(\sim 399 \mathrm{eV})$ occurs from the amine nitrogen of the free-end of HMD, while the covalently bound chlorine at the free end of PCL-CEA gives rise to a characteristic $\mathrm{Cl} 2$ p spin-orbit doublet at 200.2 and $202.0 \mathrm{eV}$ (Figure 4). More subtle indicators of surface functionalisation are also evident in the $\mathrm{C} 1 \mathrm{~s}$ photoemission (Table 2), with slight increases in intensity around $288 \mathrm{eV}$ stemming from the amide groups and at $286.6 \mathrm{eV}$ from the $\underline{\mathrm{C}}-\mathrm{N} / \underline{\mathrm{C}}-\mathrm{OH}$ contributions, along with a corresponding decrease in intensity arising from the ester groups of the substrate. No significant changes are observed in the $\mathrm{O} 1 \mathrm{~s}$ signal. This is expected since every HMD or CEA attachment leads to the hydrolysis of an ester group according to:

$$
\mathrm{O}=\mathrm{C}-\mathrm{O} \ddot{\mathrm{Y}} \mathrm{O}=\mathrm{C}-\mathrm{N}+\mathrm{C}-\mathrm{OH}
$$


and chemical shifts from oxygen moieties in $\mathrm{X}-\mathrm{C}=\mathrm{O}$ or $\mathrm{X}-\mathrm{C}=\mathrm{O}$, with different substituents $\mathrm{X}$, are generally too close to be resolved.

The relative elemental composition for PCL-HMD indicates approximately 0.8 nitrogen atomic \% present on the polymer film (Table 1). Removing contributions from some unreacted CEA hydrochloride $\left(\mathrm{NH}_{3}{ }^{+}, \mathrm{Cl}^{-}\right)$signals for the PCL-CEA film leads to $~ 1$ nitrogen atomic $\%$.

Functionalisation with the RGD peptide using the CDI method leads to further chemical modification of the surface through reaction of the amine nitrogen of PCL-HMD with the carboxylic acid of the aspartic acid terminus of RGD to form an amide bond (Figure 3, middle row). A significant increase in nitrogen results from attachment of the peptide (Table 1), with increased intensity at $400.1 \mathrm{eV}$ (Figure 3) representative of the additional amide peptide linkages and the arginine side-chain, ${ }^{[10]}$ while the slight asymmetry to high $E_{\mathrm{B}}$ values reflects the presence of $\mathrm{NH}_{3}{ }^{+}$at the free arginine $\mathrm{N}$-terminus (Table 2). ${ }^{[10,19]}$ Increased intensity is also observed for amide-specific binding energies in the $\mathrm{C} 1 \mathrm{~s}$ and $\mathrm{O} 1 \mathrm{~s}$ spectra (Figure 3) compared to PCL, along with the presence of $\underline{\mathrm{C}}-\mathrm{N}$ and $\mathrm{COO}^{-}$from the peptide. This is particularly noticeable in the oxygen spectra (Figure 3).

Because nitrogen is not present in PCL, the relative atomic \% of $\mathrm{N}$ found with XPS for the RGD-functionalised film from the CDI method (2.5\%, Table 1) was used to estimate the number of peptide moieties attached per PCL monomer unit, and thereby the surface coverage. As both HMD and RGD contain nitrogen, the level of HMD attachment needs to be determined first, and the XPS elemental composition for PCL-HMD (Table 1) corresponds to 4.1 HMD molecules per 100 PCL monomer units. The experimental O:N ratio of 8.4:1 for the peptide-modified surface, PCL-HMD-RGD (Table 1), is then compared to the O:N ratio of 6.7:1 that would occur if every PCL-HMD amine reacted with RGD. Accounting for the number of oxygen and nitrogen atoms in PCL-HMD $\left(\mathrm{C}_{12} \mathrm{H}_{26} \mathrm{~N}_{6} \mathrm{O}_{2}\right)$ and -RGD $\left(\mathrm{C}_{12} \mathrm{H}_{18} \mathrm{~N}_{6} \mathrm{O}_{5}\right)$ units, this corresponds to $2.9 \pm 0.6$ covalently bound RGD moieties per 100 PCL monomer units, or $71 \%$ of HMD amines reacted with RGD (Table 3 ).

Attachment of the RGDSC peptide with the thiol-halogen álickô method also leads to chemical modification of the aminolysed surface. The method of attachment is more directed through the use of selective nucleophilic substitution of the chlorine of PCL-CEA with the thiol sulphur of the cysteine residue of RGDSC (Figure 2), providing additional chemical indicators of reaction progress in the form of $\mathrm{S}$ presence and loss of $\mathrm{Cl}$ (Figure 4, Table 1). As with the CDI method, a significant increase in nitrogen along with alteration in carbon and 
oxygen resulted from attachment of the peptide (Tables 1 and 2). The S $2 p$ spin-orbit doublet around $164.1 \mathrm{eV}$ (Figure 4, Table 2) arises from the thiol sulphur linkage at the cysteine residue of RGDSC (Figure 1), while the absence of a chlorine signal indicates no unreacted CEA residues on PCL within the sensitivity of detection ( 0.1 atomic $\%, 1$ ppth). The improvement in selectivity for the thiol-halogen álickômethod over CDI is confirmed by the complete loss of $\mathrm{Cl}$ signal with functionalisation (Table 1).

From the relative atomic $\%$ of nitrogen $(2.0 \%$, Table 1$)$ and assuming one RGDSC molecule reacts at each chlorine terminus of PCL-CEA (suggested by the complete loss of chlorine signal with functionalisation) we obtain an experimental O:N ratio of 11.7:1 (Table 3) compared to the O:N ratio of 1.2:1 that would occur if every PCL ester group (monomer unit) was functionalised. Accounting for the number of oxygen and nitrogen atoms in PCL ($\left.\mathrm{C}_{6} \mathrm{H}_{10} \mathrm{O}_{2}-\right)$ and -CEA-RGDSC $\left(\mathrm{C}_{20} \mathrm{H}_{31} \mathrm{~N}_{9} \mathrm{O}_{9} \mathrm{~S}\right)$ units, this corresponds to an estimate of $2.1 \pm 0.4$ covalently bound RGDSC moieties per 100 PCL monomer units ( $2 \%$ coverage, Table 3). As sulphur is specific to the peptide, the O:S ratio (Table 1) could be used to independently estimate the coverage of the functionalised film: this results in $2.9 \pm 1.0$ RGDSC per 100 PCL monomer units, in good agreement with the estimate from the O:N ratio.

The changes in surface chemistry monitored by XPS indicate successful aminolysis followed by peptide attachment, with an estimate of 2-3\% peptide immobilisation for the CDI and thiol methods. This correlates well with the improvement in Schwann cell responses for the functionalised PCL films, with enhanced responses for the peptide-immobilised films (detailed investigation into cell-material interactions reported in ${ }^{[13]}$, where the positive cell response was attributed to the modified surface chemistry as no remarkable changes in surface topography and hydrophilicity were observed for the surface-modified PCL films). Both methods resulted in increased cell attachment, proliferation and lengthened Schwann cells relative to untreated PCL films, with incorporation of the peptides triggering focal adhesion plaques (as defined by Vinculin staining, Figure 5). ${ }^{[13]}$ The innovative thiol method showed good comparison with the more conventional CDI method, with a slightly higher number of focal adhesion plaques and larger cell area $\left(1952.58 \pm 315.71 \mu^{2}\right.$ and $1609.98 \pm$ $123.04 \mu \mathrm{m}^{2}$ for the thiol and CDI methods respectively), leading to some stabilisation of cell attachment and proliferation rate over time. ${ }^{[13]}$ The enhanced selectivity and reactivity for the thiol-halogen álickômethod, along with the good cell response akin to that observed for the 
widely used CDI chemistry method, ${ }^{[13]}$ demonstrates its potential for use in peripheral nerve repair.

\section{Conclusions}

XPS provides a powerful way to monitor the chemical modification of the polymer surface with peptide functionalisation, with sufficient chemical and elemental sensitivity to detect molecular species that cover only a small percentage of the organic substrate. For immobilisation of the RGD peptide sequence via CDI or thiol-halogen álickôchemistry, the nitrogen signal acts as an elemental indicator for successful attachment, along with more subtle effects in the carbon and oxygen spectra. Comparison of the XPS elemental concentrations indicates an estimate of 2-3\% peptide functionalisation on the PCL surface, accounting for the improvement in cell response observed after peptide immobilisation. The thiol-halogen álickôsurface chemistry approach to anchoring RGD peptides on PCL is more selective, reflected in the complete Cl-S reaction indicated by XPS, eliciting an enhanced cell response and making it suitable for development as a biomimetic scaffold for peripheral nerve repair.

\section{Acknowledgements}

The authors gratefully acknowledge funding from the EPSRC for a $\mathrm{PhD}+$ fellowship for JSS and the Newby Trust for PhD funding for ACDL, and current EPSRC support for JSS and SLMS through a Critical Mass Grant (EP/I013563/1). The authors would like to thank Jean-Baptiste Guilbaud and Alberto Saiani for chemistry advice on the peptide immobilisation methods.

\section{References}

[1] G. Ciardelli, V. Chiono, Macromolecular Bioscience 2006, 6, 13.

[2] F. Causa, E. Battista, R. Della Moglie, D. Guarnieri, M. Iannone, P. A. Netti, Langmuir 2010, 26, 9875.

[3] Y. Zhu, C. Gao, X. Liu, J. Shen, Biomacromolecules 2002, 3, 1312.

[4] L. Y. Santiago, R. W. Nowak, J. Peter Rubin, K. G. Marra, Biomaterials 2006, 27, 2962.

[5] M.-H. Ho, D.-M. Wang, H.-J. Hsieh, H.-C. Liu, T.-Y. Hsien, J.-Y. Lai, L.-T. Hou, Biomaterials 2005, 26, 3197.

[6] A. R. El-Ghannam, P. Ducheyne, M. Risbud, C. S. Adams, I. M. Shapiro, D. Castner, S. Golledge, R. J. Composto, Journal of Biomedical Materials Research Part A 2004, 68A, 615.

[7] U. Hersel, C. Dahmen, H. Kessler, Biomaterials 2003, 24, 4385.

[8] S. Tanuma, C. J. Powell, D. R. Penn, Surface and Interface Analysis 1994, 21, 165. 
[9] D. Briggs, M. P. Seah, P. M. A. Sherwood, in Practical Surface Analysis, Volume 1: Auger and X-ray Photoelectron Spectroscopy, 2nd ed. (Eds.: D. Briggs, M. P. Seah), John Wiley \& Sons, Chichester, 1990.

[10] J. S. Stevens, A. C. d. Luca, M. Pelendritis, G. Terenghi, S. Downes, S. L. M. Schroeder, Surface and Interface Analysis 2013, 45, 1238.

[11] D. T. Clark, J. Peeling, L. Colling, Biochimica et Biophysica Acta 1976, 453, 533.

[12] Z. Grabarek, J. Gergely, Analytical Biochemistry 1990, 185, 131.

[13] A. C. de Luca, J. S. Stevens, S. L. M. Schroeder, J.-B. Guilbaud, A. Saiani, S. Downes, G. Terenghi, Journal of Biomedical Materials Research Part A 2013, 101A, 491.

[14] C. E. Hoyle, A. B. Lowe, C. N. Bowman, Chemical Society Reviews, 39, 1355.

[15] J. S. Stevens, S. L. M. Schroeder, Surface and Interface Analysis 2009, 41, 453.

[16] J. S. Stevens, S. J. Byard, S. L. M. Schroeder, Crystal Growth \& Design 2010, 10, 1435.

[17] N. Fairley, A. Carrick, The Casa Cookbook - Part 1: Recipes for XPS Data Processing, Acolyte Science, Knutsford, Cheshire, 2005.

[18] The XPS of Polymers Database, Surface Spectra Ltd., Manchester, 2000.

[19] J. S. Stevens, S. J. Byard, C. C. Seaton, G. Sadiq, R. J. Davey, S. L. M. Schroeder, Angewandte Chemie International Edition 2011, 50, 9916. 
Table 1: Relative elemental concentrations of the PCL films from XPS (atomic $\%$ and ratios) and that expected for stoichiometric PCL.

\begin{tabular}{lcccccccc}
\hline & $\mathrm{C}$ & $\mathrm{O}$ & $\mathrm{N}$ & $\mathrm{Cl}$ & $\mathrm{S}$ & $\mathrm{C} / \mathrm{O}$ & $\mathrm{O} / \mathrm{N}$ & $\mathrm{O} / \mathrm{S}$ \\
\hline PCL expected & 75.0 & 25.0 & $/$ & $/$ & $/$ & 3.0 & $/$ & $/$ \\
PCL & 77.7 & 22.3 & $/$ & $/$ & $/$ & 3.49 & $/$ & $/$ \\
PCL-HMD & 78.9 & 20.3 & 0.8 & $/$ & $/$ & 3.89 & 25.38 & $/$ \\
PCL-HMD-RGD & 76.4 & 21.1 & 2.5 & $/$ & $/$ & 3.62 & 8.44 & $/$ \\
PCL-CEA & 79.9 & 18.1 & 1.0 & 1.0 & $/$ & 4.41 & 18.10 & $/$ \\
PCL-CEA-RGDSC & 74.3 & 23.4 & 2.0 & $/$ & 0.3 & 3.18 & 11.70 & 78.00 \\
\hline
\end{tabular}


Table 2: XPS Chemical shifts and assignments of the untreated and treated PCL films.

\begin{tabular}{|c|c|c|c|c|c|}
\hline & PCL & PCL-HMD & PCL-HMD-RGD & PCL-CEA & PCL-CEA-RGDSC \\
\hline$\underline{\text { Ci }} \mathrm{C}$ & 285.0 & 285.0 & 285.0 & 285.0 & 285.0 \\
\hline$\underline{\mathrm{C}}-\mathrm{COO}$ & 285.3 & 285.4 & 285.4 & 285.4 & 285.4 \\
\hline$\underline{\text { Cī }} \mathrm{N}$ & I & 286.6 & 286.6 & 286.6 & 286.6 \\
\hline$\underline{\mathrm{C}}-\mathrm{O}$ & 286.5 & 286.6 & 286.6 & 286.6 & 286.6 \\
\hline $\mathrm{O}=\underline{\mathrm{C}}-\mathrm{N}$ & I & 287.9 & 287.9 & 287.8 & 287.8 \\
\hline $\mathrm{COO}^{-}$ & I & l & 289.0 & I & 289.1 \\
\hline $\mathrm{O}=\underline{\mathrm{C}}-\mathrm{O}$ & 289.0 & 289.0 & 289.0 & 289.1 & 289.1 \\
\hline $\mathrm{C}-\underline{\mathrm{N}}$ & l & $\sim 399$ & l & I & I \\
\hline $\mathrm{O}=\mathrm{C}-\underline{\mathrm{N}}$ & l & 400.1 & 400.1 & 399.9 & 400.1 \\
\hline $\mathrm{H}_{2} \mathrm{~N}=\underset{\mathrm{H}}{\mathrm{N}}$ & I & I & 400.1 & I & 400.1 \\
\hline $\mathrm{C}-\underline{\mathrm{NH}}_{3}{ }^{+}$ & I & l & 401.7 & 401.7 & 401.7 \\
\hline $\mathrm{COO}^{-}$ & l & l & 532.1 & I & 531.0 \\
\hline$\underline{\mathrm{O}}=\mathrm{C}-\mathrm{O}$ & 532.1 & 532.1 & 532.1 & 532.1 & 532.0 \\
\hline$\underline{\mathrm{O}}=\mathrm{C}-\mathrm{N}$ & I & 532.1 & 532.1 & 532.1 & 532.0 \\
\hline $\mathrm{C}-\underline{\mathrm{O}}$ & I & 533.5 & 533.4 & 533.5 & 533.4 \\
\hline $\mathrm{O}=\mathrm{C}-\underline{\mathrm{O}}$ & 533.5 & 533.5 & 533.4 & 533.5 & 533.4 \\
\hline $\mathrm{C}-\underline{\mathrm{Cl}}_{(3 / 2,1 / 2)}$ & I & I & l & $200.2,202.0$ & I \\
\hline$\underline{\mathrm{Cl}}_{(3 / 2,1 / 2)}$ & I & I & l & $197.8,199.3$ & I \\
\hline $\mathrm{C}-\underline{\mathrm{S}}-\mathrm{C}_{(3 / 2,1 / 2)}$ & 1 & I & 1 & I & $163.6,164.9$ \\
\hline
\end{tabular}


Table 3: Comparison of peptide-attachment methods.

\begin{tabular}{lccc}
\hline Method & $\begin{array}{c}\text { XPS } \\
\text { O/N ratio }\end{array}$ & $\begin{array}{c}\text { \% } \\
\text { reaction }\end{array}$ & $\begin{array}{c}\text { Peptide surface } \\
\text { coverage }\end{array}$ \\
\hline $\begin{array}{l}\text { CDI } \\
\text { (PCL-HMD-RGD) }\end{array}$ & 8.44 & 71.3 & $2.9 \pm 0.6 \%$ \\
$\begin{array}{l}\text { Thiol } \\
\text { (PCL-CEA-RGDSC) }\end{array}$ & 11.7 & $\sim 100$ & $\begin{array}{c}2.1 \pm 0.4 \% \\
\text { to } 2.9 \pm 1.0 \%\end{array}$ \\
\hline
\end{tabular}

